European journal of American studies

\title{
Online Antagonism of the Alt-Right in the 2016 Election
}

Niko Heikkilä

\section{(2) OpenEdition}

\section{Journals}

Electronic version

URL: https://journals.openedition.org/ejas/12140

DOI: $10.4000 /$ ejas. 12140

ISSN: 1991-9336

Publisher

European Association for American Studies

\section{Electronic reference}

Niko Heikkilä, "Online Antagonism of the Alt-Right in the 2016 Election", European journal of American studies [Online], 12-2 | 2017, document 5, Online since 02 August 2017, connection on 08 July 2021. URL: http://journals.openedition.org/ejas/12140 ; DOI: https://doi.org/10.4000/ejas. 12140

This text was automatically generated on 8 July 2021 .

Creative Commons License 


\title{
Online Antagonism of the Alt-Right in the 2016 Election
}

\author{
Niko Heikkilä
}

\section{Introduction}

1 The 2016 election evoked concerns over the decline in the level of political discourse. Among these was the lament "Make Trolling Great Again," by which Emma Green referred to the spiteful provocations emanating from the political fringes. ${ }^{i}$ The "altright," short for alternative right, was both a harbinger and culmination of these tendencies during the election. It includes white nationalists and disillusioned rightwing dissidents who draw from theories like neoreaction, a political theory that is contemptuous of modernism, democracy, and egalitarianism, and favors a form of "nondemocratic system with rule-driven succession." ${ }^{1 i}$ As an online movement, it also has firm links with participatory media networks through websites such as 4chan, 8chan, and Reddit, along with meme and troll culture. ${ }^{i i i}$ The alt-right capitalized on the anti-immigration and anti-establishment campaign themes of Donald Trump to thrust its ideas into the political mainstream. Just as Trump made use of social media, the altright utilized memes-and like Trump, the movement attracted attention and visibility through provocations and sensationalism.

2 This orientation can also be understood as a part of the broader contemporary political landscape. Along with the decline of traditional party politics and the emergence of forms of anti-politics, ${ }^{\text {iv }}$ scholars have identified the increasing stylization of politics where emphasis on aesthetic features of appearance and performance is important. ${ }^{v}$ For example, Frank Ankersmit's contention of interaction and interference, of collapsing of style and content, seems to fit the meme-ing efforts of the alt-right as well as the grandiose rhetoric of Trump. ${ }^{\mathrm{vi}}$ As scholars of political communication have noted, Trump's reality TV status and brand name combined various pop culture elements with populism, eschewing the separation between entertainment and politics. ${ }^{\text {vii }}$ Likewise, similar stylistic and rhetorical maneuvers can be found with regard 
to the alt-right. In an intensely mediated and stylized landscape, the notions of spectacle and celebrity have become essential features of politics. viii Understanding the role of the popular in carrying political messages more generally, as argued by John Street, is not just "about persuading people through the force of the argument," but also "about capturing the popular imagination, about giving acts and ideas symbolic importance." "ix Street's reasoning points to the possibilities of popular codes of communication, which can be used to advance a diverse set of goals and are part of a more complex relationship.

3 In a study of white nationalism and popular culture, C. Richard King and David J. Leonard draw out some of these interconnections: "The efforts from white nationalists to produce their own popular culture products in opposition to mainstream films, music, video games, and other cultural productions, some of which we too consume, illustrate the way in which white nationalists penetrate and engage the mainstream daily." ${ }^{\mathrm{x}}$ While the alt-right did not engage with popular culture in these terms, its oppositional efforts included adopting pop culture references and the use of Internet memes, which were notably present during the 2016 election. Also, the movement's engagement with and creation of a unique style and terminology means that its ideology has been somewhat difficult to understand and it has remained isolated within certain corners of the Internet, reaching only likeminded online supporters. However, among the contributing factors and mechanisms through which new political actors gain power, the media, when coupled with "the popular," "can form dangerously intolerant alliances," as Liesbeth van Zoonen reminds. ${ }^{x i}$ In this context, the election campaigns of Trump and Clinton, along with the media, channeled the alt-right, at least momentarily, into the broader political conversation. Therefore, the purpose and goal of this article is to position the rise of the alt-right against the background of the electoral process and to link its ideological elements with the efforts and tactics to engage and shape the broader political discourse. First, in order to understand how the alt-right "swayed the election," I will examine the movement and its actions in relation to the media and the Trump and Clinton campaigns. Secondly, drawing from previous studies on online antagonisms ${ }^{\mathrm{xi}}$ and memetic media, ${ }^{\text {xii I }}$ will examine how visual and rhetorical means facilitated and popularized the "alt-right's" controversial messages in the 2016 election.

\section{The Alternative Right in the Making}

4 A number of media pundits and analysts have attempted to outline key features of the alt-right. However, the amorphous, ideologically diffuse, and largely online movement has inevitably posed difficulties for attempts to describe, explain, or fit it into a simple narrative. For movement conservatives, George Hawley argues, free market principles, traditional values, and aggressive foreign policy have been "the three legs of the conservative stool." ${ }^{\text {xiv }}$ The alt-right movement, in contrast, breaks from conservative foreign policy and free trade orthodoxy in favor of higher cultural ideals, coalescing around issues they oppose, namely multiculturalism, (non-white) immigration, feminism, and "political correctness." ${ }^{\mathrm{xv}}$ Indeed, one of the unifying factors is the belief that mainstream conservatives have sold out white people as a group. "As the movement grew and diversified," Shane Burley suggests, "it has become a catchall for an Internet focused white nationalism." "xvi If movement conservatism was defined by 
William F. Buckley, alt-right members have been influenced by and often cite ideas of thinkers like H. L. Mencken (skepticism of democracy and egalitarianism), Julius Evola (traditionalism), Oswald Spengler (cultural pessimism and organic and a cyclical vision of history), and Friedrich Nietzsche ("will to power," iconoclasm). ${ }^{\text {vvii }}$ Hence, culture is seen as the primary value and a site of political action, often expressed in racial terms as preservation of white culture and identity.

5 As the term "alt-right" gained publicity, media coverage commonly situated it in relation to Donald Trump. Linking the alt-right's newly found prominence to the ethos of the Trump campaign, Rosie Gray summarized the movement as "white supremacy perfectly tailored to our times: 4chan-esque racist rhetoric combined with a tinge of Silicon Valley-flavored philosophizing, all riding on the coattails of the Trump boom." "xviii Other mainstream commentators expressed similar sentiments, taking note of the growing enthusiasm of white nationalists for Trump's primary campaign. . $^{\mathrm{ix}}$ Dylan Matthews, however, argues that the alt-right is "more than a simple rebranding of the white nationalist movement." Instead, he sees it as the "mutated revival of a monster William F. Buckley thought he killed in the early 1990s, given new energy by the web," referring to the influence of the John Birch Society, Pat Buchanan, and paleoconservatism (a political philosophy which, among other things, stresses restrictions on immigration, economic nationalism, and isolationist foreign policy). ${ }^{\mathrm{xx}}$ According to Matthews, the alt-right finds its most notable expression not only in rejection of mainstream conservatism but in the form of neoreaction. ${ }^{x \times i}$ Among the intellectual origins of the alt-right are the foundational texts of neoreaction like Nick Land's "The Dark Enlightenment." xxii

6 If the ideology of neoreaction is characterized by the rejection of democracy and reform altogether, then for Richard Spencer, the President of the National Policy Institute (NPI), a white nationalist think tank, the central element of the alt-right is found in the notion of "identitarianism." Spencer sees identitarianism as being "fundamentally about difference, about culture as an expression of a certain people at a certain time."xxiii The identitarian position is related to the ideas of "race realism" or "human biodiversity" (HBD) advanced in magazines and on websites like American Renaissance, Radix Journal, and Taki's Magazine. This racial ideology manifests in terms of distinction and inequality, whereby not only individuals but racial groups are seen as unequal in relation to each other. ${ }^{\text {xxiv }}$ For example, the founder of American Renaissance, Jared Taylor, has questioned the equality of the races and advocates the idea that "[s]ome races are better at some things than others." ${ }^{x x v}$ Spencer, in turn, has promoted similar views about race, which he sees as forming the ideological core of the alt-right. Among other things, "Spencer's so-called 'race realism,' according to Shane Burley, "underpins theories of racial hierarchy, and the idea that it has a basis in biology." xxvi While some strains of the alt-right, like neoreaction, reject white nationalism, the latter notion forms the core of the movement, which includes neo-Nazi elements, with more moderate non-ideological online provocateurs lurking on the edges of the radical right. xxvii

7 Spencer and Taylor have adopted softer or, ironically, "politically correct" terms like "identitarianism" and "human biodiversity." However, the editor of the neo-Nazi website Daily Stormer, Andrew Anglin, is more straightforward. He identifies antiSemitism, scientific racism, white nationalism, opposition to gender equality, cultural normalization, and common sense economics as elemental values in his guide to the 
movement. For Anglin, irony is a central element that creates confusion in the mainstream culture. "The true nature of the movement is, however, serious and idealistic," Anglin writes. Ideological seriousness is represented in and has taken the form of irony as part of the postmodern condition: "[I]t was my contention that in an age of nihilism, absolute idealism must be couched in irony in order to be taken seriously." "xxviii This nihilistic ethos is closely linked to online activities through meme and troll culture, as well as conspiracy theorizing. In order to get people to accept ideas which were previously too controversial, Anglin strives both to entertain and to inform, to appear serious and playful at the same time. .xix $^{\text {xix }}$

The prevalence of meme and troll culture is echoed in a widely circulated article, "An Establishment Conservatives Guide to the Alt-Right," by Allum Bokhari and former Breitbart News tech editor and political provocateur Milo Yiannopoulos. In an attempt to explain and defend the alt-right, they diverge from the ideological commitments of Spencer, Taylor, and Anglin. Instead, Yiannopoulos and Bokhari highlight the altright's subcultural origins, citing imageboard sites such as 4chan and 8chan as the central support network for the movement. For these youthful and subversive online communities, shock value is a basis for action. Yiannopoulos and Bukhari acknowledge the evident racism of some of the comments and images but argue that the message is only a means to elicit reactions and should not be taken seriously. In support of this, they draw parallels with the 1960s counterculture:

Just as the kids of the 60s shocked their parents with promiscuity, long hair and rock'n'roll, so too do the alt-right's young meme brigades shock older generations with outrageous caricatures, from the Jewish 'Shlomo Shekelburg' to 'Remove Kebab,' an internet in-joke about the Bosnian genocide. These caricatures are often spliced together with Millennial pop culture references, from old 4chan memes like pepe the frog, to anime and My Little Pony references. ${ }^{\mathrm{xxx}}$

On the one hand, the article was condemned in the mainstream as a defense of a racist movement. On the other, it revealed tensions between ideological distinctions and commitments. Andrew Anglin, for example, adamantly opposed the idea that they weren't serious, describing Yiannopoulos as a "kike infiltrator" who was threatening the movement. In his in-depth analysis, Luke O'Brien observes that "Yiannopoulos had exposed a rift between the Spencer and Anglin wings of the alt-right." While both advocate white nationalism, different goals separate Anglin and Spencer. O'Brien sees Anglin as a purist and Spencer as someone who reaches beyond core ideological commitments. ${ }^{\text {xxi }}$ Thus, their main distinction concerns tactics and style. To put this in a broader context, Roger Griffin has examined what he refers to as the process of metapoliticization of fascism. By this he means the post-war political climate in which it was impossible to attract any kind of mass following or to build a political party around fascist ideology, even as the production of ideological discourses took on different guises that could operate outside of organized politics. In particular, Griffin notes that the European New Right (Nouvelle Droite) has provided the most sophisticated disguise for the radical right by adopting a form over content approach, which includes emulating academic production in terms of discourse and format. ${ }^{\text {xxii }}$ Similar tendencies can be seen regarding the alt-right, albeit with often oppositional styles. For example, Anglin has embraced a hardline approach while leading the alt-right's "meme and troll brigade," whereas Spencer has aimed to operate with a "softer" means and intellectual tone (NPI, Radix Journal, etc.), aligning with the European New Right in many respects. Hence, along with the metapolitical approach and ethno-nationalist principles, Spencer 
and other prominent alt-right figures adopted the term "identitarian" from the European New Right. ${ }^{\text {xxxiii }}$

Amongst different ideological, tactical, and stylistic approaches, commonalities arise in the cultivation of a position that sees white male identity as threatened. This conviction is expressed in exaggerated language and conspiratorial terms like "white genocide." xxxiv Another striking feature is that most of the members are young, white men, often described as tech-savvy and college-educated, who use social media, message boards, and memes to convey ideas. ${ }^{\mathrm{xxx}}$ Aja Romano points out that antifeminist causes, including the "men's rights" movement, provided a crossover point from the online "manosphere" to alt-right communities. ${ }^{\text {xxvi }}$ Dexter Thomas captures the element of "marketing strategy" for racial politics: "They're making being racist cool again for a certain class of people." ${ }^{\text {xxxvii }}$ These contemporary modes blend with traditionalist positions that, among other things, see the West in decline and call for the reinstatement of traditional hierarchies and roles. A favorite pop culture allusion and key concept is the notion of "red-pilled," which, in reference to the movie The Matrix, is used to describe "awakening to the underlying realities" (alt-right, neoreaction, racial, etc.).xxxviii Most broadly, members of the alt-right are united in their opposition to "political correctness," which, as Nicole Hemmer points out, also functions as a cover for racism, misogyny, and anti-Semitism. . $^{\text {xxix }}$ In the context of the elections, different strands have also been tied together by their support for Donald Trump. Taken together, stylistic elements, the nihilistic ethos, and ideological positions are intrinsically linked to the wider objective to alter the Overton window, referring to the range of acceptable ideas within public debate. Some ideas are deemed as unthinkable and thus fall outside the window. ${ }^{\mathrm{xl}}$ Hence, through the Trump campaign, there was an opportunity to inject alt-right ideas into mainstream U.S. politics by means of visual and rhetorical provocations.

\section{Trump Support Online: Antagonizing the Conservative Establishment}

11 Perhaps the most vocal online support for Trump was channeled through websites like Reddit, 4 chan, and 8 chan. In addition to enthusiasm for the Trump campaign, 4chan and especially its "politically incorrect" /pol/ board has been increasingly interpreted as an intersection of online culture and alt-right ideas. ${ }^{x l i}$ For example, Oliver Lee has reported how alt-right ideas started to resonate with many /pol/ users, who then adopted extremist rhetoric in order to combat what they describe as an "anti-white agenda" in the mainstream culture. When Trump attacked immigration and political correctness, these views were then echoed and amplified on 4chan and similar online sites, solidifying his growing online support base. In accordance with meme and troll culture, one user described Trump as "meme-able" and "entertaining" and said that through Trump, alt-right "ideas have gained much greater influence." $x$ lii On Reddit, $r$ / The_Donald became the most popular subreddit for a presidential candidate, receiving close to 52 million views in March 2016, "up from 12.6 million in February and 1.3 million in January." Benjy Sarlin writes that "[t]he goal was to foster a community where Trump fans could be themselves in all their glory without apology.... It's since spread to the broader network of Trump supporters." xliii 

originated from a white nationalist Twitter account. The graphic claimed that black people kill $81 \%$ of white homicide victims. The claim was checked and called "racially loaded" and "wildly inaccurate" by PolitiFact. xliv This kind of flirtation with white nationalist ideas prompted Andrew Anglin to describe it as "wink-wink-wink" strategy, as a kind of subtle recognition of these views on Trump's part. ${ }^{\text {xlv }}$ In turn, some alt-right Trump supporters adopted the term "Glorious Leader" in reference to Trump. In July 2016, Trump tweeted an image of Clinton next to a pile of dollars and a Jewish star with the words "Most Corrupt Candidate Ever" imprinted on it. Andrew Anglin clearly saw the tweet as a part of the "wink-wink-wink" strategy, as he wrote that "[ $t]$ his is, yet again, dog-whistling by the Leader." Alongside numerous anti-Semitic comments, some Daily Stormer users wondered whether Trump got the meme from the /pol/ board, where it had appeared earlier. ${ }^{\text {xlvi }}$ Based on the enthusiastic reception, perhaps Anglin was not that far off with his assessment regarding the "wink-wink-wink" strategy.

Less ambiguously, by March 2016 Breitbart News was seen as being heavily intertwined with the Trump campaign. At the same time, more solid links between the website and the alt-right were established. ${ }^{\text {xlvi }}$ In July, the executive chairman of Breitbart News, Stephen Bannon, declared in an interview that it is "the platform for the alt-right." xlviii Although the "alt-right's" origins lie elsewhere, Breitbart News was "the entering wedge, the link between the alt-right and the mainstream right," as Nicole Hemmer noted. ${ }^{\text {lix }}$ The appointment of Bannon as the chief executive of Trump campaign best exemplifies the extent of these connections.

In contrast to Breitbart News, National Review came to epitomize the anti-Trump sentiments within the mainstream of conservatism. The antipathy of National Review toward Trump and his supporters reflected the magazine's historical gatekeeper role of conservative opinion. The founder of National Review, William F. Buckley, successfully excised "unsavory ideological elements" like the John Birch Society out of the movement. In the age of the Internet and social media, however, the role of the establishment gatekeepers has waned, as revealed in February 2016, when National Review dedicated an entire issue to discredit Trump but with seemingly little impact. ${ }^{1}$ These mutual antipathies led to a controversy as early as September 2015.

Under the headline "No Movement That Embraces Trump Can Call Itself Conservative," Jonah Goldberg attacked the "corrupting of conservatism." For Goldberg, the "corruptors" of conservatism were Trump and his supporters, and he compared them to liberals enthralled with celebrities: "We laugh at liberals who let know-nothing celebrities do their thinking for them. Well, many people we laughed at are now laughing at us because we are going ga-ga over our own celebrity."li The column elicited a hostile reaction, including anti-Semitic abuse on social media, and it provoked a wider backlash against National Review as the hashtag "NRORevolt" began trending on Twitter. As part of a long-standing critique of movement conservatives, the revolt used a popular expression, the slur "cuckservative," short for "cuckolded conservative."lii Although the "cuckservative" narrative gained prominence after Rush Limbaugh called Trump critics "cuckolded Republicans," Jeet Heer locates the origins of the term in white nationalist websites, where it is used to refer to white conservative (race) "sellout." liii The "cuckservative" narrative represented the anti-establishment mood embodied by the alt-right. It intertwined subcultural jargon and ideas of 
masculinity and race, all elemental for the controversies that led the alt-right to be widely recognized and discussed.

The original meaning of "cuckold" refers to a man with an unfaithful wife, whereas its racial undertones derive from its current association as a genre of porn. Milo Yiannopoulos rejected the idea that the popularization of the term emanated from white nationalist websites with the racial characteristics associated with the porn genre. Instead, he emphasized its provenance from 4chan, where "cuck" is used as an insult for someone who is surrendering or selling out supporters. He saw the popularization as a testimony of the increasing influence of online culture amid many right-wing supporters. ${ }^{\text {liv }}$ Alternatively, Richard Spencer diverged from this interpretation, embracing the racial narrative: “The \#cuckservative meme doesn't make any sense without race. It's all about race.... What's powerful about \#cuckservative is that it is a call for racially conscious politics[.]"lv In effect, the "cuckservative" narrative resonated widely because it was articulated through overlapping layers of potential meaning: the recognizable metaphor had racist connotations and an anti-establishment bent, both of which shift with ease between different contexts. ${ }^{\text {lvi }}$ The meme was given emotional weight through the heightened emphasis on masculinity and white identity.

17 For example, Spencer stated that "Trump is a big part of the 'cuckservative' phenomenon," not because of his ideology, but because he is a "tougher and superior man than 'conservatives' and seems to grasp the demographic displacement of European-Americans at a visceral level." "lvii While the Trump campaign did not directly take part in the "cuckservative" meme, it can be argued that it provoked similar, albeit subtler, sentiments. Following an argument by Ryan Milner and Whitney Phillips, Trump's campaign platform itself was not based upon solid ideas, but built around resonant memes. By evoking memetic ideas, such as the notion of "Crooked Hillary," he managed to exploit existing anxieties and biases. Marco Rubio as "little Marco" and Jeb Bush as "low-energy Jeb," he tapped into broader ideas of "emasculated conservatives," which in turn were amplified through memes. As formulated by Milner and Phillips: "These ideas are memetic; each resonates independent of factual realities, to the point of countering factual realities." ${ }^{\text {lix }}$ The "cuckservative" meme, besides being an example of popularization of alt-right ideas, served as a reminder of increasing online and social media antagonism in the election.

\section{4. "Attention is Their Life Force": Alt-Right in the (Social) Media Spotlight}

18 A typical example of a social media campaign instigated by the alt-right was the harassment of the comedy actor Leslie Jones, which garnered increasing media attention for the alt-right, with even Hillary Clinton taking time to comment and criticize the movement. Following the release of the new Ghostbusters movie in July 2016, Milo Yiannopoulos and a number of his followers and members of the alt-right community started to abuse Leslie Jones on social media. In response to the harassment campaign, which was full of sexism, racism, and odious memes, Jones started to retweet some of the abusive messages she had received, which led Twitter to take note and ultimately ban Yiannopoulos from the service. The worst vitriol against Jones ceased for a moment, but returned in late August when her personal website was hacked. ${ }^{1 \mathrm{x}}$ The 
racist harassment and hacking of Jones served, as Aja Romano writes, as "a flashpoint in the alt-right's escalating culture war." $x i$ The movement's problematic relationship with the media was outlined by Chava Gourarie: "[I]f the primary purpose of the altright is to provoke, then attention is their life force and media attention their fuel." As a direct attack on racial and gender identity, this posed a paradox: repeating aggressive rhetoric and racist imagery has the risk of perpetuating their circulation, while ignoring the behavior has the risk of ignoring their potential consequences. ${ }^{\text {.xiii }}$

In her article on the online activist collective Anonymous and 4chan, Whitney Phillips has examined the commonalities between trolling and media practices and how they feed into each other, describing it as a kind of cybernetic feedback loop. She argues that an accrual of "lulz"-adapted from a misspelling of "lol"-counts for trolls as the accrual of capital does for the media, as it is serious business that seeks to gain the biggest possible audience. Phillips notes that similarities between trolls and media arise from their common investment in spectacle, and she argues that trolls specifically seek to exploit the sensationalist practices and other dominant tendencies in contemporary culture. . ${ }^{\text {liv }}$ In the case of the alt-right, however, the notion of "trolling" is misleading, as the use of the term has been increasingly criticized. For example, Romano observes that the online performance of trolling increasingly overlaps with real life. To view the propagation of racist memes by members of the alt-right as mere trolling, on the basis of which one might dismiss the behavior, distorts the actual message and downplays the ideology behind it. ${ }^{1 \times v}$ Phillips had made a similar argument about characterizations of Trump as a troll. In particular, Phillips points out that the troll description not only trivializes his actual behavior and comments, but is in fact dangerous, for it establishes a distance between actions and words. ${ }^{\text {lxvi }}$

On August 25, 2016, Hillary Clinton decided to voice her support for Jones in a tweet stating that "no one deserves this--least of all someone who brings us so much joy." "lxvii The tweet came soon after her much-discussed speech in Reno that criticized the rhetoric emanating from the Trump campaign and for the first time featured a mention of the alt-right by a presidential candidate. According to Clinton, "From the start, Donald Trump has built his campaign on prejudice and paranoia. He is taking hate groups mainstream and helping a radical fringe take over the Republican party. His disregard for the values that make our country great is profoundly dangerous." "Ixviii The objective of the speech was to highlight the links between the Trump campaign and hate groups, singling out the alt-right by name. Clinton listed some of the most incendiary remarks, for example, citing Trump's role in the birther movement and his derogatory comments about Mexican immigrants. Clinton went on to accuse Trump of empowering fringe elements by his refusal to condemn racist comments and "pushing discredited conspiracy theories with racist undertones."

The focus on Trump's history was followed by comments about the appointment of Stephen Bannon as a campaign CEO. Clinton summarized Breitbart News as a platform for "ideas on the extremist fringe of the conservative right." $1 \times x$ Although the speech was promoted as a denunciation of the alt-right, the movement itself was explicitly mentioned only briefly toward the end of the speech. "These are racist ideas. Racebaiting ideas. Anti-Muslim, anti-immigrant, anti-women-all key tenets making up an emerging racist ideology known as the "Alt-Right," clinton said. The ideology of the alt-right, as Clinton saw it, was given relevance by the "de facto merger between Breitbart and the Trump Campaign." 
As expected, Trump lashed out and accused Clinton of "pandering to the worst instincts in our society" and "race-baiting to try to get African-American voters." "xxii However, George Hawley noted that "[i]n order to have this speech make any sense, she's going to have to explain what the alt-right is-anime Nazis and frog memes... and undercurrents of white supremacy." He also reflected the concern that this was seen as evidence that they are "playing a role in the 2016 election."1xxiii Indeed, leading voices of the alt-right were delighted to be denounced by Clinton, and they reveled in the national spotlight. Ixxiv As Clinton's speech made them the focus of attention, this was seen as the legitimatization they had been waiting for. Andrew Anglin wrote on the day of the speech: "Well guys. We've made it. Hillary Clinton is giving a speech about us today." ${ }^{x x v}$ Richard Spencer told the Wall Street Journal that their "fundamental obstacle was people having no idea who we are." Therefore, in Spencer's view, this mention of the movement by a presidential candidate meant that they had "made it."

In particular, these remarks were a reflection of the fact that the alt-right was less interested in specific policy issues and more focused on influencing the election process in a rather general way. Subsequently, the campaigns of both Clinton and Trump, however ambiguously, provided a platform through which it could extend its sphere of influence. Whitney Phillips notes rhetorical and behavioral overlaps between Anonymous and the alt-right, as well as similarities in their rise: "In each case, previous insular communities were transformed into forces to be reckoned with. Into monsters, all through the repeated chanting of their name."1xxvii The transformation of the altright is perhaps best embodied in the movement's keen interest in pop culture and aesthetics, both of which are informed by the notion of metapolitics. Luke O'Brien observes that "for Spencer and his clique, that process isn't about influencing policy but rather the way people saw the world, which would naturally lead to policy changes." 1 xxviii Succinctly put, metapolitics refers to a struggle that is ultimately social and cultural rather than political. In this context, Clinton's speech was seen as an opportunity to engage with a much wider audience and to reframe narratives in their own terms.

\section{Memetic Hate: Pepe the Frog}

If the use of memes is characteristic for the alt-right, then one meme in particular characterizes the role of the movement in the election: a popular cartoon frog. In September, Hillary Clinton's campaign explained that a recent iteration of Pepe the Frog was a symbol of white supremacy. There ensued considerable confusion about why a presidential candidate was focusing on a cartoon frog. ${ }^{\text {lxix }}$ 


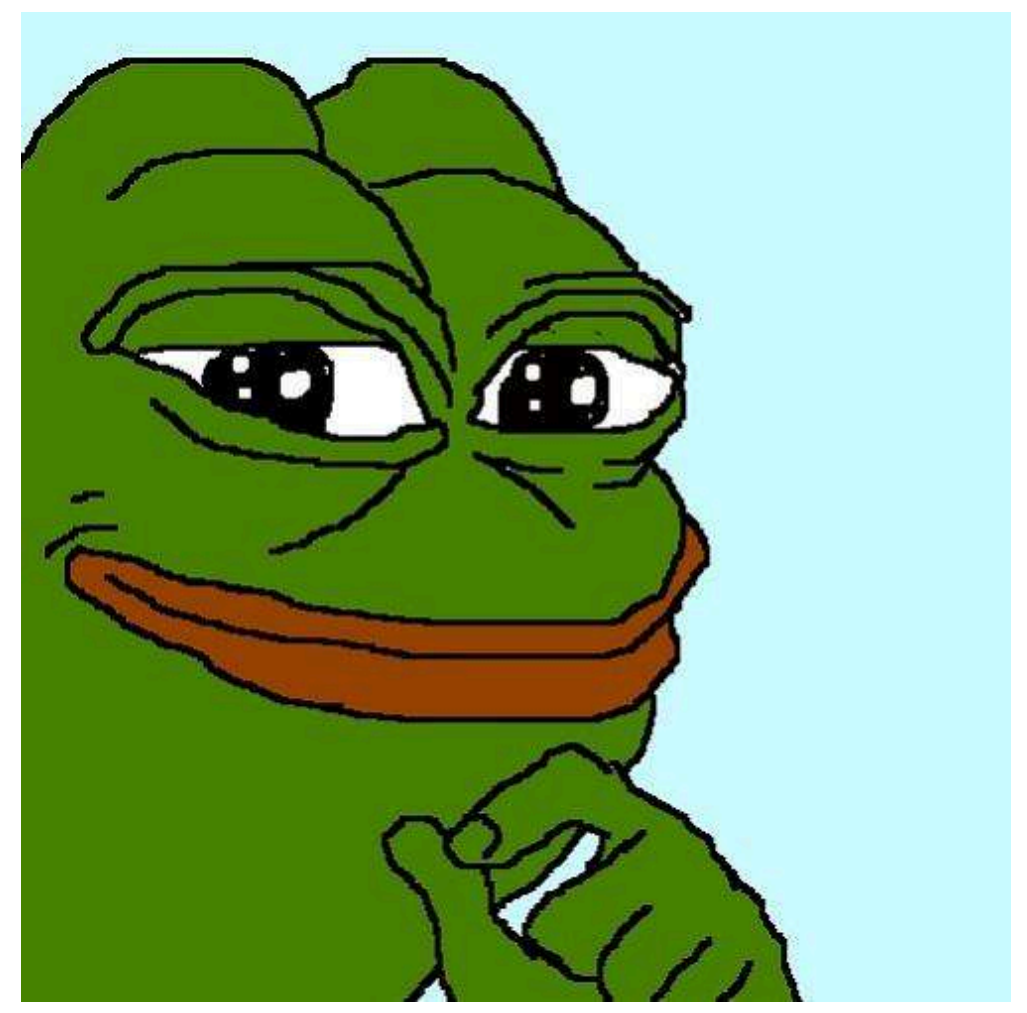

Pepe the Frog, which was originally invented by comic artist Matt Furie in 2005 and featured as an anthropomorphic character in a popular comic series Boy's Club, has since become a subcultural online phenomenon, in particular on 4chan where the meme transmuted into countless different forms and contexts, expressing a variety of emotions. ${ }^{\text {lxxi }}$ During the election, Pepe became a prominent Twitter avatar for many Trump supporters. Among the popular iterations were images of Pepe as Trump, who himself tweeted one such image in October 2015. 1xxxii 


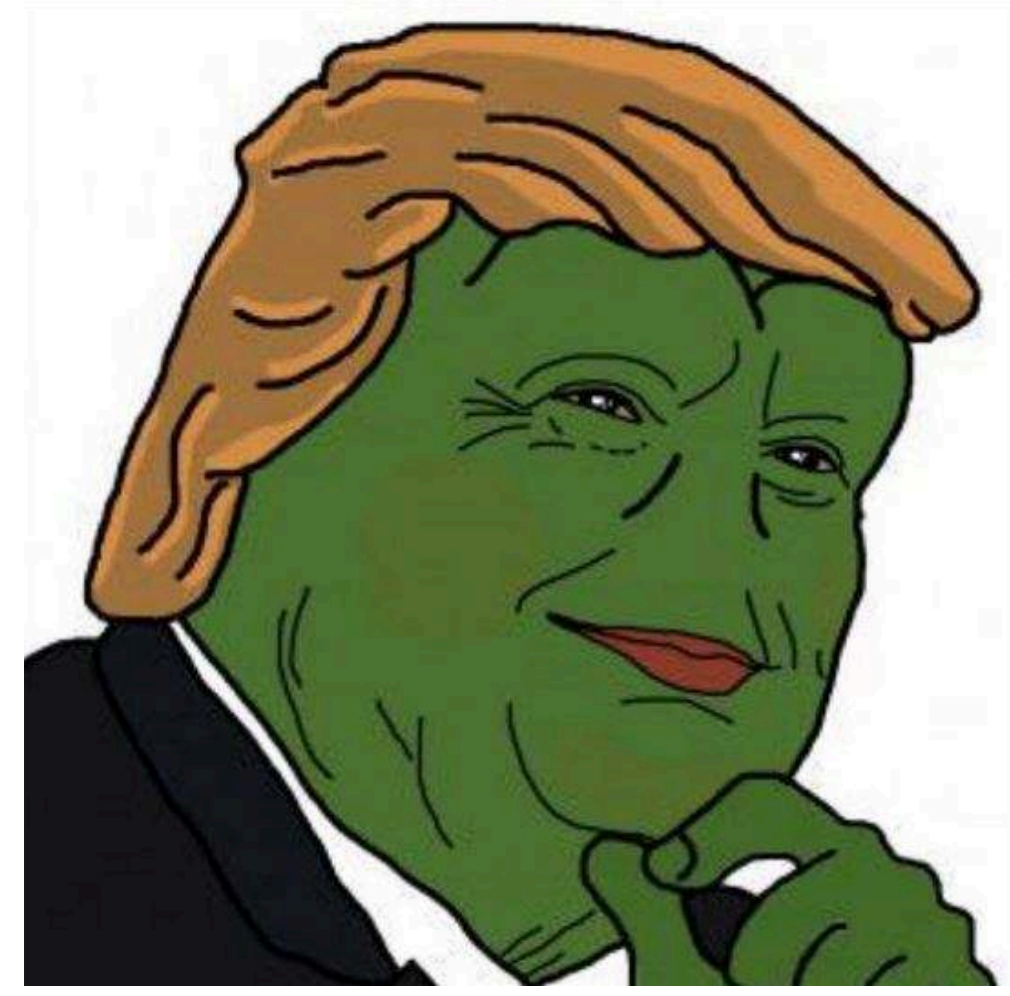

Figure 2. "Very Rare Pepe," Imgur. lxxxiii

The alt-right association to Pepe came from anti-Semitic and racist illustrations in which Pepe was decorated with Nazi and white supremacist symbols. This prompted the Clinton campaign to issue the warning that "in recent months, Pepe's been almost entirely co-opted by white supremacists who call themselves the 'alt-right," labeling Pepe as "a symbol associated with white supremacy." "1xxiv $T$ The racist iterations of Pepe were used to draw a line between the alt-right and the Trump campaign. To put this in context, from one perspective, as argued by Jesse Singal, the offensive illustrations were born out of online troll culture guided by a desire to provoke outrage. ${ }^{\mathrm{lxxxv}}$ From another perspective, Nicole Hemmer suggested that Trump in fact "validated many of their [alt-right] points of view, as well as their stylistic approach."1xxvvi In this sense, Pepe assumed significance as an embodiment of the stylistic approach of the alt-right.

While the creator has no control over the meanings that people give to memes, the white supremacy connection was explained by Whitney Phillips: "Pepe might not mean white supremacy inherently but 'Pepe means white supremacy' becomes a meme that perpetuates that connection regardless." Ryan Milner's argument echoes this: "In the memetic struggle for Pepe's fate, racist associations are pretty loud and therefore winning out." "|xxvvii The debate over Pepe is a reminder of how online forums operate as a source of cultural production, as well as a site of contestation of specific meanings. The appropriation of popular media, as Milner points out, functions as a way to create a novel impression that is central to the resonance of memetic texts. Milner advances the idea that the employment of memetic logics gives the public a means to "create, circulate, and transform texts in the name of political expression." He cites the example of the Guy Fawkes mask, which intertwines a populist message and pop culture, and examines its transformation from "a symbol of failure" into "a rallying cry for social justice." In contrast to the example given by Milner, Pepe was transformed 
from a harmless cartoon character into a symbol of hate, but the memetic logics are the same in both cases. ${ }^{\text {lxxxviii }}$

The peculiarity of Pepe's transformation is that it enabled both campaigns to attack each other. Addressing a LGBT gala audience on September 9, Clinton stated, "Just to be grossly generalistic, you could put half of Trump supporters into what I call the basket of deplorables-the racist, sexist, homophobic, xenophobic, Islamophobic, you name it." "Ixxix Clinton called their rhetoric offensive and hateful and blamed Trump for giving a voice to the "deplorables." Her comments were followed by a storm of criticism, with almost two-thirds of Americans objecting to them as unfair. While Clinton later regretted the "half" part, she still insisted that many Trump supporters fit into those categories. ${ }^{\text {xc }}$ Clinton's characterization was seen by Trump, on the other hand, as a testimony of her true feelings and bigotry, as "contempt and disdain for so many great Americans." Chip Berlet observed that Trump also made use of the comment by fitting it into his populist rhetoric about liberal elites. Instead of rejecting it, Trump supporters embraced the label and turned it into a kind of unofficial campaign slogan. ${ }^{\text {xi }}$

Soon the label was harnessed in images that combined a populist message with popular culture. In one example, an image from the musical Les Misérables was Photoshopped and turned into a "Les Deplorables" meme. On September 16, 2016, it was also notably present at a Trump rally in Miami: when Trump entered the stage, the "Les Deplorables" meme was projected behind his podium and "Do You Hear the People Sing?" from the musical was played, as to emphasize "the song of angry men." Trump then opened with the remark "Welcome to all of you deplorables." xcii Here the meme, with its intertextual popular culture references, was used as an explicit commentary by Trump. In contrast to "liberal elites" and Clinton's comments, the symbolism of Les Misérables channeled the populist image of Trump as the "man of the people."

In another meme, the title of the popular action film The Expendables was changed to "The Deplorables," and the faces of Donald Trump, Roger Stone, Alex Jones, and Pepe, among others, were superimposed on the characters' bodies on the movie poster.

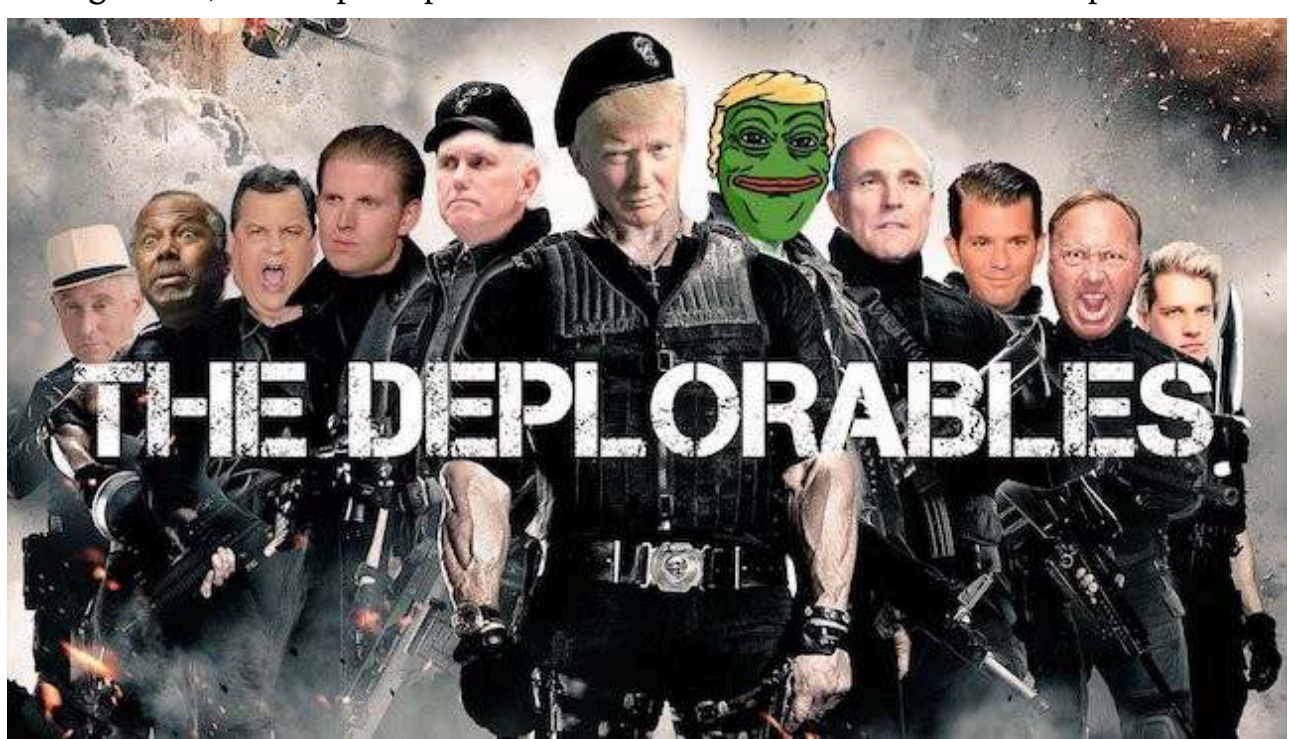

Figure 3. "The Deplorables," Know Your Meme. ${ }^{\text {xciii }}$

Donald Trump, Jr., who was also featured in the meme, posted the image on social media. "Apparently I made the cut as one of the Deplorables," Trump, Jr. wrote. 
Trump's adviser Roger Stone also shared the image, saying he was "so proud to be one of the Deplorables." Due to the racist iterations of Pepe, criticism was directed at the Trump campaign, forcing them to issue a statement that they did not "deliberately use the symbols and code white supremacists use to signal their allegiance." xciv Trump, Jr. declared that he had never heard of Pepe and was not aware of any negative connotations ${ }^{\mathrm{xcv}}$ However, the fact that he and Stone posted the image with Pepe meant that they were certainly aware of the cartoon frog. Conversely, "The Deplorables" image was used by the Clinton campaign as an example of the Trump campaign and white nationalist connections. In particular, the Clinton campaign stressed the fact that Trump, Jr. and Stone had posted the image on social media. Thus, they tried to demonstrate that the Trump campaign continued to strengthen its ties with the altright. Going full circle, a meme that was born out of a much-criticized comment by Clinton was used to criticize the Trump campaign.

The controversy about Pepe the Frog and the publicity it received in the presidential race culminated in an announcement by the Anti-Defamation League: "The AntiDefamation League (ADL) today identified 'Pepe the Frog,' a cartoon character used by haters on social media to suggest racist, anti-Semitic or other bigoted notions, as a hate symbol." Pepe the Frog was added to ADL's "Hate on Display" database because of its racist incarnations, which were designed to "harass and spread hatred on social media," according to CEO Jonathan A. Greenblatt. In June, ADL also added the (((echo))) symbol to its database after it was co-opted by the alt-right and used as visual grammar to identify Jewish people on social media, metaphorically echoing the old conspiracy of Jews having global influence. ${ }^{\text {ccvi }}$

These appropriations depend upon the ability to exploit pre-existing cultural texts only to impose new oppositional meanings. The explainers and statements from both campaigns point to the unforeseen ways in which electoral discussions can be and were stirred by controversial memes and appropriations. If there was confusion over form and content in attempts to understand the alt-right, then Pepe and other images were crucial in spreading those messages, functioning as symbols that expressed and evoked emotions. ${ }^{\text {xcvii }}$ These appropriations exemplify contemporary oppositional efforts, which are not merely a sign of provocation but a means of engaging the political mainstream.

\section{Conclusion}

Soon after Donald Trump's election victory, members of the alt-right gathered to celebrate at a meeting in Washington, D.C. In the presence of many media outlets, Richard Spencer was the final speaker at the NPI conference. Spencer declared in reference to "meme-magic" that, "though we may use these terms half-jokingly, they represent something truly important, the victory of will." He then added, "We willed Donald Trump into office, we made this dream into reality." The speech touched upon ideas of white identity: "America was, until this last generation, a white country, designed for ourselves and our posterity. It is our creation and our inheritance, and it belongs to us." At one point in the speech, Spencer declared "Hail Trump! Hail Our People! Hail Victory!" while some members of the audience raised their arms in the Nazi salute. ${ }^{\text {xcvii }}$ When Trump was confronted with these statements in an interview by the New York Times, he officially disavowed the alt-right. Specifically, Trump said: "Of 
course I condemn. I disavow and I condemn."xcix Trump may not need the alt-right anymore, but whether the alt-right needs Trump anymore remains an open question.

On one hand, Trump ambivalently never embraced the more hardline views within the alt-right, nor did he, until the election was finished, explicitly denounce the movement. On the other hand, while Hillary Clinton had no trouble connecting Trump with the altright, her speech gave the group its biggest mainstream platform and a considerable amount of media coverage. Arguably the alt-right was not so much a political force, but a cultural force online, as offensive terms and imagery associated with the movement surfaced in the mainstream throughout the election cycle. The fact that the alt-right did not fit neatly into existing media narratives about white supremacy or white nationalism also entailed a lack of coherent narrative to counter the confusion. Nicole Hemmer refers to "the problem of journalistic wonder at racism that comes in unexpected packages," noting the trap of focusing on style over the substance of racism. ${ }^{\mathrm{c}}$

Like Hemmer, Kelly J. Baker reminds us in the New York Times that the kind of image makeover the alt-right was engaging in is not new, pointing out that "efforts to dress up white supremacy" in fact have a precedent. She notes, "While it might seem newsworthy that today's alt-right members wear suits and profess academic-sounding racism, they are an extension of these previous white supremacist movements, dressed up in 21st-century lingo, social media and fashion."ci Drawing attention to the tools with which the alt-right engages the mainstream should also be a means to understand the objectives beneath the new style and mode. As the movement assumes different ideological positions that do not necessarily complement each other, it is important to identify and understand their differences alongside their commonalities. A more nuanced understanding should also posit these underlying ideologies, stylistic gestures, and promotional tactics in relation to the dominant cultural and political tendencies.

\section{NOTES}

i. Emma Green, "Make Trolling Great Again," The Atlantic, September 14, 2016, accessed January 21, 2017, http://www.theatlantic.com/politics/archive/2016/09/make-trolling-great-again/ 499523/.

ii. Dylan Matthews, "The alt-right is more than warmed-over white supremacy. It's that, but way way weirder," Vox, August 25, 2016, accessed December 11, 2016, http://www.vox.com/2016/4/18/11434098/alt-right-explained.

iii. For example, Dylan Matthews, "The alt-right is more than warmed-over white supremacy. It's that, but way way weirder," Vox, August 25, 2016, accessed December 11, 2016, http:// www.vox.com/2016/4/18/11434098/alt-right-explained; Rick Jervis, "Defining alt-right is tricky in the wake of Trump's victory," USA Today, November 24, 2016, accessed January 16, 2017, http://www.usatoday.com/story/news/2016/11/24/alt-right-white-supremacist-donald-trump/ 94355492/; Jeff Nesbit, "What is the Alt-Right?," U.S. News \& World Report, September 12, 2016, accessed January 21, 2017, http://www.usnews.com/news/articles/2016-09-12/what-is-the-altright; Allum Bokhari and Milo Yiannopoulos, “An Establishment Conservatives Guide to the Alt- 
Right," Breitbart News, March 29, 2016, accessed December 13, 2016, http://www.breitbart.com/ tech/2016/03/29/an-establishment-conservatives-guide-to-the-alt-right/.

iv. Peter Mair, Ruling the Void: The Hollowing of Western Democracy (London and New York: Verso, 2013).

v. See, for example, John Corner and Dick Pels, "Introduction: The Re-Styling of Politics," in Media and the Restyling of Politics: Consumerism, Celebrity, and Cynicism, eds. John Corner and Dick Pels (London: Sage, 2003).

vi. Frank Ankersmit, Political Representation (Stanford: Stanford University Press, 2002), 135.

vii. Chris Wells et al., "How Trump Drove Coverage to the Nomination: Hybrid Media Campaigning," Political Communication 33, no. 4 (2016): 669-670, doi: 10.1080/10584609.2016.1224416.

viii. For example, see Mel van Elteren, "Celebrity Culture, Performative Politics, and the Spectacle of 'Democracy' in America," Journal of American Culture 36, no. 4 (2013): 263-283, doi: 10.1111/jacc.12049; John Street, "The Transformation of Political Modernity?," in New Media and Politics, eds. Barrie Axford and Richard Huggins (London: SAGE, 2001).

ix. John Street, Politics \& Popular Culture (Cambridge: Polity Press, 1997), 57.

x. C. Richard King and David J. Leonard, Beyond Hate: White Power and Popular Culture (Farnham: Ashgate, 2014), 6-7.

xi. Liesbet van Zoonen, Entertaining the Citizen: When Politics and Popular Culture Converge (Lanham: Rowman \& Littlefield Publishers, 2005), 147.

xii. Whitney Phillips, This is Why We Can't Have Nice Things Online: Mapping the Relationship Between Online Trolling and Mainstream Culture (Cambridge, MA: MIT Press, 2015).

xiii. Ryan M. Milner, The World Made Meme: Public Conversations and Participatory Media (Cambridge, MA: MIT Press, 2016).

xiv. George Hawley, "The 2016 Election and the End of the Conservative Movement," University Press of Kansas Blog, September 15, 2016, accessed January 18, 2017, http:// universitypressblog.dept.ku.edu/uncategorized/the-2016-election-and-the-end-of-theconservative-movement/. On the origins and rise of American conservatism, see George Hawley, Right-Wing Critics of American Conservatism (Lawrence: University Press of Kansas, 2016), 19-36.

xv. NPR, "What You Need To Know About The Alt-Right Movement," NPR, August 26, 2016, accessed January 20, 2017, http://www.npr.org/2016/08/26/491452721/the-history-of-the-altright.

xvi. Shane Burley, "Defining the Alt Right and the New American Fascism," Counterpunch, September 28, 2016, accessed January 19, 2017,

http://www.counterpunch.org/2016/09/28/defining-the-alt-right-and-the-new-americanfascism/.

xvii. H. L Mencken has a club named after him, which has attracted many prominent white nationalist academics and writers. Like Mencken, alt-right writers admire Nietzsche, and Nietzschean themes such as egoism and nihilism permeate alt-right thinking. As Burley notes, Spencer "used to jokingly refer to himself as a Nietzsche-con." Shane Burley, "Defining the Alt Right and the New American Fascism." See also George Hawley, Right-Wing Critics of American Conservatism, 207-242.

xviii. Rosie Gray, "How 2015 Fueled The Rise Of The Freewheeling, White Nationalist Alt-Right Movement," BuzzFeed, December 28, 2015, accessed December 10, 2016, https:// www.buzzfeed.com/rosiegray/how-2015-fueled-the-rise-of-the-freewheeling-white-nationali? utm_term=.oh7LLXzNxW\#.tbZXXwG2Y7.

xix. Ian Tuttle, “Trump's White-Nationalist Fans Discredit His Candidacy," National Review, September 10, 2015, accessed December 11, 2016, 
http://www.nationalreview.com/article/423849/trumps-white-nationalist-fans-discredit-hiscandidacy-ian-tuttle; "How White Nationalist Groups Found Their Candidate In Donald Trump," NPR, September 3, 2015, accessed December 11, 2016,

http://www.npr.org/2015/09/03/437195328/how-white-nationalist-groups-found-theircandidate-in-donald-trump.

xx. Dylan Matthews, "The alt-right is more than warmed-over white supremacy." Since the founding of National Review in 1955, Buckley was until his death in 2008 a key figure in defining the ideological boundaries of conservatism. For a detailed discussion on conservative purges after World War II and paleoconservatism, see George Hawley, Right-Wing Critics of American Conservatism, 37-73, 178-206.

xxi. Dylan Matthews, "The alt-right is more than warmed-over white supremacy."

xxii. Computer programmer Curtis Yarvin, who writes under the pseudonym Mencius Moldbug, has defined key elements of neoreaction, or "The Dark Enlightenment," in two separate blog posts which, together with fellow thinker Nick Land's pamphlet "The Dark Enlightenment," form the ideological core of neoreaction. See "The Dark Enlightenment," accessed January 17, 2017, http://www.thedarkenlightenment.com/.

xxiii. Richard Spencer, "Identitarianism - A Conversation Starter," Radix Journal, June 6, 2015, accessed December 12, 2016,

http://www.radixjournal.com/journal/2015/6/15/identitarianisma-conversation-starter.

xxiv. Shane Burley, "Defining the Alt Right and the New American Fascism."

xxv. Quoted in Jason Wilson, “The races are not equal': meet the alt-right leader in Clinton's campaign ad," The Guardian, August 26, 2016, accessed December 12, 2016,

https://www.theguardian.com/us-news/2016/aug/26/jared-taylor-alt-right-clinton-trump.

xxvi. Quoted in Jason Wilson, “'A sense that white identity is under attack': making sense of the alt-right," The Guardian, August 23, 2016, accessed December 12, 2016,

https://www.theguardian.com/us-news/2016/aug/23/alt-right-movement-white-identity-

breitbart-donald-trump.

xxvii. On neoreaction, see George Hawley, Right-Wing Critics of American Conservatism, 292-293. For a discussion on radical right terminology, see Roger Eatwell, "Introduction: The new extreme right challenge," in Western Democracies and the New Extreme Right Challenge, eds. Roger Eatwell and Cas Mudde (London: Routledge, 2004), 1-16.

xxviii. Andrew Anglin, “A Normie's Guide to the Alt-Right," The Daily Stormer, August 31, 2016, accessed December 12, 2016, http://www.dailystormer.com/a-normies-guide-to-the-alt-right/.

xxix. See Luke O'Brien, “My Journey to the Center of the Alt-Right," The Huffington Post Highline, November 3, 2016, accessed December 13, 2016,

http://highline.huffingtonpost.com/articles/en/alt-right/.

xxx. Allum Bokhari and Milo Yiannopoulos, "An Establishment Conservatives Guide to the AltRight," Breitbart News, March 29, 2016, accessed December 13, 2016,

http://www.breitbart.com/tech/2016/03/29/an-establishment-conservatives-guide-to-the-altright/.

xxxi. Luke O'Brien, "My Journey to the Center of the Alt-Right," The Huffington Post Highline, November 3, 2016, accessed December 13, 2016,

http://highline.huffingtonpost.com/articles/en/alt-right/.

xxxii. Roger Griffin, "Interregnum or Endgame? The radical right in the 'post-fascist' era," in The Populist Radical Right: A Reader, ed. Cas Mudde (Abingdon: Routledge, 2017), eBook Collection EBSCOhost, accessed May 5, 2017, 19-25.

xxxiii. The European New Right or Nouvelle Droite is an intellectual movement that has been sometimes referred to as the "Gramscianism of the Right." Shane Burley writes that Spencer has drawn from metapolitical approaches developed by European nationalists to build "a sort of Frankfurt school of the radical right." See Shane Burley, "Defining the Alt Right and the New 
American Fascism." In 2015, Radix Journal held an essay competion on Identitarianism. See "Why I'm an Identitarian," Radix Journal, accessed May 5, 2017, http://www.radixjournal.com/2015essay-contest. Given that the European New Right is openly anticapitalist, anti-Christian, and anti-American, it has garnered little interest in the U.S. However, as George Hawley notes, white nationalists from the farthest right-wing fringes are "the American ideologues most willing to seriously engage with the European New Right." Besides Spencer, Radix Journal, and the NPI, Occidental Quarterly and its website embrace metapolititcs and are influenced by Traditionalism and the European New Right. Also leading New Right thinkers like Guillaume Faye and Alain de Benoist have given talks in conferences organized by American Renaissance and the NPI. See George Hawley, Right-Wing Critics of American Conservatism (Lawrence: University Press of Kansas, 2016), 241-242, 264-265.

xxxiv. Anti-Defamation League, “Alt Right: A Primer About the New White Supremacy," accessed January 20, 2017, http://www.adl.org/combating-hate/domestic-extremism-terrorism/c/alt-right-a-primerabout-the.html?referrer=https://www.google.fi/\#.WIMe6loLTIU?referrer=http://www.adl.org/ combating-hate/domestic-extremism-terrorism/c/alt-right-a-primer-about-the.html.

xxxv. Southern Poverty Law Center, “Alternative Right," accessed January 21, 2017, https:// www.splcenter.org/fighting-hate/extremist-files/ideology/alternative-right.

xxxvi. Aja Romano, "How the alt-right's sexism lures men into white supremacy," Vox, December 14, 2016, accessed January 21, 2017,

http://www.vox.com/culture/2016/12/14/13576192/alt-right-sexism-recruitment.

xxxvii. Quoted in Chava Gourarie, "How the 'alt-right' checkmated the media," Columbia Journalism Review, August 30, 2016, accessed January 19, 2017,

http://www.cjr.org/analysis/alt_right_media_clinton_trump.php.

xxxviii. Andy Wachowski and Larry Wachowski, The Matrix, film, Warner Bros., 1999. Beyond the red pill and the blue pill, the alt-right jargon includes the black pill, referring to "pure egoism, nihilism and destruction." See Colin Liddell, "The Black Pill," Radix Journal, October 6, 2015, accessed January 21, 2017,

http://www.radixjournal.com/journal/2015/10/6/the-black-pill.

xxxix. Nicole Hemmer, “The Alt-Right Rises," U.S. News \& World Report, August 23, 2016, accessed January 20, 2017,

http://www.usnews.com/opinion/articles/2016-08-23/conservatives-have-lost-their-party-todonald-trump-and-the-alt-right.

xl. Nathan J. Russell, "An Introduction to the Overton Window of Political Possibilities," Mackinac Center for Public Policy, January 4, 2006, accessed December 14, 2016, https://www.mackinac.org/ 7504.

xli. Emiliano De Cristofaro, "4chan raids: how one corner of the internet is spearing its shadows," The Conversation, November 8, 2016, accessed December 14, 2016, https://theconversation.com/ 4chan-raids-how-one-dark-corner-of-the-internet-is-spreading-its-shadows-68394. See also Gabriel Emile Hine et al., “A Longitudinal Measurement Study of 4chan's Politically Incorrect Forum and Its Effect on the Web," arXiv: 1610.03452v3, November 7, 2016, accessed December 14, 2016, https://arxiv.org/abs/1610.03452.

xlii. Quoted in Oliver Lee, "Understanding Trump's Troll Army," Vice Motherboard, March 13, 2016, accessed December 14, 2016, http://motherboard.vice.com/read/understanding-trumpstroll-army.

xliii. Quoted in Benjy Sarlin, "How An Army of Pro-Donald Trump Trolls Are Taking Over Reddit," NBC News, April 14, 2015, accessed December 14, 2016,

http://www.nbcnews.com/politics/2016-election/how-army-pro-donald-trump-trolls-aretaking-over-reddit-n556036. 
xliv. Jon Greenberg, “Trump's Pants on Fire tweet that blacks killed $81 \%$ of white homicide victims, PolitiFact, November 23, 2015, accessed December 15, 2016, http://www.politifact.com/truth-o-meter/statements/2015/nov/23/donald-trump/trumptweet-blacks-white-homicide-victims/. A study by George Washington University's center for extremism found that among white nationalists on Twitter \#WhiteGenocide was the most popular theme, followed by Trump and Trump-related hashtags, J.M. Berger, "Nazis Vs. ISIS on Twitter: A Comparative Study of White Nationalist and ISIS Online Social Media Networks," GW Program On Extremism, September 2016, accessed December 15, 2016, https://cchs.gwu.edu/sites/ cchs.gwu.edu/files/downloads/Nazis\%20v.\%20ISIS\%20Final_0.pdf.

xlv. Jeet Heer, “The Method to Trump's Twitter Madness," The New Republic, July 5, 2016, accessed December 16, 2016, https://newrepublic.com/article/134841/method-trumps-twitter-madness.

xlvi. Andrew Anglin, “Glorious Leader Tweets Hillary Image with Dollars and Jew Star," The Daily Stormer, July 2, 2016, accessed May 2, 2017, https://bbs.dailystormer.com/t/glorious-leadertweets-hillary-image-with-dollars-and-jew-star/38184. I would like to thank the anonymous reviewer for bringing this source to my attention.

xlvii. Chava Gourarie, "How the 'alt-right' checkmated the media," Columbia Journalism Review, August 30, 2016, accessed January 19, 2017,

http://www.cjr.org/analysis/alt_right_media_clinton_trump.php.

xlviii. Sarah Posner, “How Donald Trump's New Campaign Chief Created an Online Haven for White Nationalists," Mother Jones, August 22, 2016, accessed December 17, 2016, http:// www.motherjones.com/politics/2016/08/stephen-bannon-donald-trump-alt-right-breitbartnews.

xlix. Nicole Hemmer, "The Alt-Right Rises," U.S. News \& World Report, August 23, 2016, accessed January 20, 2017,

http://www.usnews.com/opinion/articles/2016-08-23/conservatives-have-lost-their-party-todonald-trump-and-the-alt-right.

1. Justin Dyer, "The Decline of Movement Conservatism and the Rise of the Alt-Right," Public Discourse, November 17, 2016, accessed January 20, 2017,

http://www.thepublicdiscourse.com/2016/11/18253/.

li. Jonah Goldberg, "No Movement That Embraces Trump Can Call Itself Conservative," National Review, September 5, 2015, accessed December 15, 2016,

http://www.nationalreview.com/g-file/423607/no-movement-embraces-trump-can-call-itselfconservative-jonah-goldberg.

lii. Matthew Yglesias, “\#NRORevolt, explained,” Vox, January 21, 2016, accessed January 21, 2017, http://www.vox.com/2015/9/8/9276719/nrorevolt-cuckservatives.

liii. Jeet Heer, "Conservatives Are Holding a Conversation About Race," The New Republic, July 26, 2015, accessed December 15, 2016,

https://newrepublic.com/article/122372/conservativesareholdingconversationaboutrace.

liv. Milo Yiannopoulos, “'Cuckservative' Is a Gloriously Effective Insult That Should Not Be Slurred, Demonized, or Ridiculed," Breitbart News, July 28, 2015, accessed December 15, 2016, http://www.breitbart.com/big-government/2015/07/28/cuckservative-is-a-gloriously-effectiveinsult-that-should-not-be-slurred-demonised-or-ridiculed/.

lv. Quoted in Chauncey Devega, "The secret history of "cuckservative": The fetish that became a right-wing rallying cry," Salon, August 9, 2015, accessed December 15, 2016, http:// www.salon.com/2015/08/09/

the_secret_history_of_cuckservative_the_fetish_that_became_a_right_wing_rallying_cry/.

lvi. On polyvocality, see Ryan M. Milner, "Pop Polyvocality: Internet Memes, Public Participation, and the Occupy Wall Street Movement," International Journal of Communication 7 (2013): 2357-2390.

lvii. Quoted in David Weigel, "'Cuckservative' - the conservative insult of the month, explained," The Washington Post, July 29, 2015, accessed December 15, 2016, https:// 
www.washingtonpost.com/news/the-fix/wp/2015/07/29/cuckservative-the-conservative-insultof-the-month-explained/?utm_term=.fd223e2f84cb.

lviii. Ryan M. Milner and Whitney Phillips, "Dark magic: the memes that made Donald Trump's victory," US Election Analysis 2016: Media, Voters and the Campaign, accessed December 16, 2016, http://www.electionanalysis2016.us/us-election-analysis-2016/section-6-internet/dark-magicthe-memes-that-made-donald-trumps-victory/. After Trump's victory, the Washington Post reported on the celebrations on 4chan's /pol/ boards, citing one user whose comment captured the mood: "We actually elected a meme as president." See Abby Ohlheiser, "We actually elected a meme as president': How 4chan celebrated Trump's victory," The Washington Post, November 9, 2016, accessed May 5, 2017, https://www.washingtonpost.com/news/the-intersect/wp/ 2016/11/09/we-actually-elected-a-meme-as-president-how-4chan-celebrated-trumps-victory/? utm_term=.e6ca561d6b07.

lix. Ryan M. Milner and Whitney Phillips, “Dark magic: the memes that made Donald Trump's victory."

lx. Anna Silman, “A Timeline of Leslie Jones's Horrific Online Abuse," New York Magazine, August 24, 2016, accessed December 16, 2016, http://nymag.com/thecut/2016/08/a-timeline-of-lesliejoness-horrific-online-abuse.html.

lxi. Aja Romano, "The Leslie Jones hack is the flashpoint of the alt-right's escalating culture war," Vox, August 26, 2016, accessed January 18, 2017,

http://www.vox.com/2016/8/26/12653474/leslie-jones-hack-alt-right-culture-war.

lxii. Chava Gourarie, "How the 'alt-right' checkmated the media," Columbia Journalism Review, August 30, 2016, accessed January 19, 2017,

http://www.cjr.org/analysis/alt_right_media_clinton_trump.php.

1xiii. Whitney Phillips, "The Alt-Right Was Conjured Out of Pearl Clutching and Media Attention," Vice Motherboard, October 12, 2016, accessed December 16, 2016,

http://motherboard.vice.com/read/conjuring-the-alt-right.

lxiv. Whitney Phillips, "The House That Fox Built: Anonymous, Spectacle, and Cycles of Amplification," Television and New Media 14 no .6 (2012): 494-509. doi: 10.1177/1527476412452799.

lxv. Aja Romano, "How the alt-right uses internet trolling to confuse you into dismissing its ideology," Vox, November 23, 2016 accessed December 16, 2016,

http://www.vox.com/2016/11/23/13659634/alt-right-trolling.

lxvi. Whitney Phillips, “Donald Trump Is Not A Troll," Slate, June 23, 2016, accessed December 16, 2016,

http://www.slate.com/articles/technology/future_tense/2016/06/

the_problems_with_calling_donald_trump_a_troll.html.

lxvii. Hillary Clinton, Twitter post, August 25, 2016, 1: 38 pm, https://twitter.com/ HillaryClinton/status/768910514688815105?ref_src=twsrc\%5Etfw.

lxviii. Hillary Clinton, "Remarks on Trump's Prejudice and Paranoia in Reno, NV," August 25, 2016, accessed December 17, 2016, https://www.hillaryclinton.com/speeches/remarks-ontrumps-prejudice-and-paranoia-in-reno-nv/.

lxix. Ibid.

lxx. Ibid.

lxxi. Ibid.

lxxii. "Donald Trump: Hillary Clinton "should be ashamed" of alt-right speech," CBS News, August 25, 2016, accessed December 18, 2016, http://www.cbsnews.com/news/donald-trump-hillaryclinton-should-be-ashamed-for-alt-right-speech/.

lxxiii. Quoted in Maria L. La Ganga, “Clinton slams Trump's 'racist ideology' that ushers hate groups into mainstream," The Guardian, August 26, 2016, accessed January20, 2017, https:// www.theguardian.com/us-news/2016/aug/25/hillary-clinton-alt-right-racism-speech-donaldtrump-nevada. 
lxxiv. Alan Rappeport, "Hillary Clinton Denounces the 'Alt-Right,' and the Alt-Right Is Thrilled," The New York Times, August 26, 2016, accessed December 18, 2016,

http://www.nytimes.com/2016/08/27/us/politics/alt-right-reaction.html.

lxxv. Andrew Anglin, “Clinton's Alt-Right Speech Today-Live on the Daily Stormer!,” The Daily Stormer, August 25, 2016, accessed December 18, 2016,

http://www.dailystormer.com/clintons-alt-right-speech-today-live-on-the-daily-stormer/.

lxxvi. Beth Reinhard, “'Alt-Right' Enters the Political Limelight," The Wall Street Journal, August 24, 2016, accessed December 19, 2016, http://www.wsj.com/articles/alt-right-enters-thepolitical-limelight-1472081850.

lxxvii. Whitney Phillips, "The Alt-Right Was Conjured Out of Pearl Clutching and Media Attention," Vice Motherboard, October 12, 2016, accessed December 16, 2016,

http://motherboard.vice.com/read/conjuring-the-alt-right

lxxviii. Luke O'Brien, “My Journey to the Center of the Alt-Right," The Huffington Post Highline, November 3, 2016, accessed December 13, 2016,

http://highline.huffingtonpost.com/articles/en/alt-right/.

lxxix. For example, Jesse Singal, "How Internet Trolls Won the 2016 Election," New York Magazine, September 16, 2016, accessed January 21, 2017,

http://nymag.com/selectall/2016/09/how-internet-trolls-won-the-2016-presidentialelection.html.

lxxx. Know Your Meme, "Pepe the Frog," accessed March 15, 2017,

http://knowyourmeme.com/memes/pepe-the-frog.

lxxxi. Ibid.

lxxxii. Donald J. Trump, Twitter post, October 13, 2015, 1:53 am, https://twitter.com/realDonaldTrump/status/653856168402681856?ref_src=twsrc\%5Etfw.

lxxxiii. Imgur, “Very rare Pepe," September 30, 2015, accessed January 21, 2017,

http://imgur.com/gallery/9fnb25E.

lxxxiv. Elizabeth Chan, "Donald Trump, Pepe the frog, and white supremacists: an explainer," September 12, 2016, accessed December 29, 2016,

https://www.hillaryclinton.com/feed/donald-trump-pepe-the-frog-and-white-supremacists-anexplainer/.

lxxxv. Jesse Singal, "How Internet Trolls Won the 2016 Election.".

lxxxvi. Quoted in Rick Jervis, "Defining alt-right is tricky in the wake of Trump's victory," USA Today, November 24, 2016, accessed January 16, 2017,

http://www.usatoday.com/story/news/2016/11/24/alt-right-white-supremacist-donald-trump/ 94355492/

lxxxvii. Jason Koebler, "Hillary Clinton Is Right: Pepe Is a White Supremacist," Vice Motherboard, September 14, 2016, accessed December 29, 2016,

http://motherboard.vice.com/read/hillary-clinton-is-right-pepe-is-a-white-supremacist.

lxxxviii. Ryan M. Milner, The World Made Meme, 153, 157-160.

lxxxix. CBS News, "Hillary Clinton says half of Trump's supporters are in a 'basket of deplorables," September 10, 2016, accessed January 12, 2017, available on Youtube: https:// www.youtube.com/watch?v=PCHJVE9trSM.

xc. Aaron Blake, "Voters strongly reject Hillary Clinton's 'basket of deplorables' approach," The Washington Post, September 26, 2016, accessed January 3, 2017, https://www.washingtonpost.com/news/the-fix/wp/2016/09/26/voters-strongly-reject-hillaryclintons-basket-of-deplorables-approach/?utm_term=.b2e63bb6c4ee.

xci. Matt Kwong, "How Trump turned 'deplorables' into a campaign rallying cry," CBC News, September 14, 2016, accessed January 3, 2017, http://www.cbc.ca/news/world/donald-trumpdeplorables-rallying-cry-alt-right-hillary-clinton-meme-1.3760971. The Trump campaign also 
released a "Deplorables" ad; see Donald J. Trump, "Trump Campaign Launches New TV Ad: 'Deplorables,"' October 5, 2016, accessed March 15, 2017,

https://www.donaldjtrump.com/press-releases/trump-campaign-launches-new-tv-ad-

deplorable.

xcii. Bloomberg Politics, “Deplorable Entrance: Trump Takes Stage To 'Les Mis' Song," September 16, 2016, accessed January 13, 2017, available on Youtube:

https://www.youtube.com/watch?v=TEiTKloMgBg.

xciii. Know Your Meme, "Hillary Clinton's 'Basket of Deplorables," accessed January 19, 2017, http://knowyourmeme.com/memes/events/hillary-clinton-s-basket-of-deplorables.

xciv. Dawn Chmielewski, “Internet memes emerge as 2016 election's political dog whistle," USA Today, September 30, 2016, accessed January 4, 2017,

http://www.usatoday.com/story/tech/news/2016/09/30/internet-memes-white-house-electionpresident/91272490/.

xcv. Nick Gass, “Trump Jr.: 'I've never heard of Pepe the Frog,"' Politico, September 16, 2016, accessed January 4, 2017, http://www.politico.com/story/2016/09/donald-trump-jr-pepe-thefrog-228268.

xcvi. Anti-Defamation League, "ADL Adds 'Pepe the Frog' Meme, Used by Anti-Semites and Racists, to Online Hate Symbols Database," accessed January 21, 2017,

http://www.adl.org/press-center/press-releases/extremism/adl-adds-pepe-the-frog-online-

hate-symbols-database.html\#.WGYjbVOLTIV.

xcvii. On pop culture images and symbols, see Peter Dahlgren, Media and Political Engagement: Citizens, Communication, and Democracy (Cambridge: Cambridge University Press, 2009), 137.

xcviii. Red Ice TV, "Richard Spencer - NPI 2016, Full Speech," November 21, 2016, accessed January 16, 2017, available on YouTube: https://www.youtube.com/watch?v=Xq-LnO2DOGE.

xcix. "Donald Trump's New York Times Interview: Full Transcript," The New York Times, November 23, 2016, accessed January 21, 2017,

http://www.nytimes.com/2016/11/23/us/politics/trump-new-york-times-interview-

transcript.html.

c. Nicole Hemmer, "Tweedy racists and 'ironic' anti-Semites: the alt-right fits a historical pattern," Vox, December 2, 2016, accessed December 29, 2016, http://www.vox.com/the-big-idea/ 2016/12/2/13814728/alt-right-spencer-irony-racism-punks-skinheads.

ci. Kelly J. Baker, "White-Collar Supremacy," The New York Times, November 25, 2016, accessed December 29, 2016, http://www.nytimes.com/2016/11/25/opinion/white-collarsupremacy.html.

\section{ABSTRACTS}

Buoyed by the populist campaign of Donald Trump, the "alt-right," a loose political movement based around right-wing ideologies, emerged as an unexpected and highly contentious actor during the election cycle. The alt-right promoted controversy through provocative online actions that drew a considerable amount of media attention. This article focuses on the role of the "altright" in the 2016 election by examining its visual and rhetorical efforts to engage the political mainstream in relation to the campaigns of Donald Trump and Hillary Clinton. In particular, the alt-right's unique style and internal jargon created notable confusion and also attracted interest 
by the media, while its promotional tactics included the use of social media and Internet memes, through which the movement came to epitomize online antagonism in the 2016 election.

\section{INDEX}

Keywords: alt-right, Internet, anti-establishment, white nationalism, radical right, online movements, Internet memes 